Original Research Paper

\title{
Friendly Environmental Transport
}

\author{
${ }^{1}$ Relly Victoria V. Petrescu, ${ }^{2}$ Raffaella Aversa, ${ }^{2}$ Antonio Apicella and ${ }^{1}$ Florian Ion Tiberiu Petrescu \\ ${ }^{I}$ ARoTMM-IFToMM, Bucharest Polytechnic University, Bucharest (CE), Romania \\ ${ }^{2}$ Advanced Material Lab, Department of Architecture and Industrial Design, \\ Second University of Naples, 81031 Aversa (CE), Italy
}

\author{
Article history \\ Received: 06-07-2017 \\ Revised: 09-12-2017 \\ Accepted: 24-01-2018 \\ Corresponding Author: \\ Florian Ion Tiberiu Petrescu \\ ARoTMM-IFToMM, Bucharest \\ Polytechnic University, \\ Bucharest (CE), Romania \\ Email: scipub02@gmail.com
}

\begin{abstract}
The shipments were absolutely necessary at all times, but still, have polluted and damaged the environment. Humanity is struggling between technological tests of deployment of new types of mild transport for the environment and the need to maintain still in the operation the machines already polluting products in large quantity, cheaper, more convenient economically, that customers have already been accustomed. This work is trying to make a radiography of the new technologies friendly environment which have been implemented or can be implemented in the future. Are shown on the short and tests for the implementation of transport on the basis of the hydrogen. It also highlighted the possibilities of the changeover to the electric modern cars. And what about the air quality would not be filled with carbon monoxide, carbon dioxide, that we might be able to restore the planet clean air, shields recovered and climate its initial soft and normal, that we could breathe normally again, our children and grandchildren.
\end{abstract}

Keywords: Friendly Environmental Transport, Sustainable Transport, Flexible Transport, Hydrogen Transport, Electric Transport

\section{Introduction}

The shipments were absolutely necessary at all times. Development and diversification of road vehicles and other vehicles, especially the automotive, together with the thermal engines, in particular, those with internal combustion (being the most compact, more robust and more independent, more reliable, more powerful, more dynamic, etc...), has forced and development at a faster rate of devices, the mechanisms and assemblies components, but still have polluted and damaged the environment (Barrett and Odum, 2000; EU Bulletin, 1996; 2001; 2004; 2005).

The problem of the yield of the very low, a large nuisances and consumption very high power and fuel by the mechanisms of the timing cover, has been greatly improved and regulated in the past 20-30 years through the development and introduction of some mechanisms of modern distribution, which besides the yields higher and optimal functioning, are free from noise, vibrationfree, with fuel-consumption diminished, under the circumstances in which the engine speed for the maximum possible has increased from about 5 000-6 000 to about 30000 [rpm].
A special performance is a further increase in the mechanical efficiency of the mechanism of main engine and the distribution systems, up to the high quotas until the fact that will bring a saving of major fuels (Mahalingam and Ramesh Bapu, 2013; Petrescu, 2012). Today all internal combustion engines (but also those with external combustion which are still used) operate in general at the highest standards, with small levels of fuels with low levels of vibration and noise, with emissions extremely low, corresponding to the current regulations which are more and more drastic (Petrescu et al., 2017 a-v).

The oil reserve and the current energy of mankind are limited. But until the implementation of new energy sources (which to take control of the real in place fossil fuels) an alternative source of the actual energy and fuels is even "reduce fuel consumption of a motor vehicle", or that we will burn the oil, gas and derived fuels, either that we will implement in a first stage the biofuels (this is why they had to be carried out in some countries such as Brazil, United States, Germany, etc) and later and hydrogen (extracted from the water), (Anderson, 1984; Petrescu et al., 2016a-c; Aversa et al., 2017).

Hydrogen, the core element of life with a single nucleon (proton) in the component core or, hydrogen can 
be obtained from virtually any (through different chemical reaction, nuclear, etc), although abound in the universe, in our galaxy and in our system the solar and yet it is very little present on Earth, but instead it can extract and of the water in the huge amounts and the energy efficiency of the extraction of has become even acceptable, the devices required for the storage of being already well placed at the point and by the burning of to be non-interlaced for thermal power and water so that the hydrogen does not pollute the atmosphere as they do it hydrocarbons alcohols, vegetable oils, or other fuels, so that the hydrogen it would be the ideal as fuel if it be extracted from the water and burned Immediately, without storage.

If we use an electric motor instead of the classic proposed for the use of hydrogen, energy consumption would be about 10 times less. Let us assume that we want to cut more nuisances, produced by a heat engine which operate on the basis of hydrocarbons and move this engine on the hydrogen. If the energy used for the liquefaction of and storage of hydrogen required is about 10 times larger and even more and often is used to obtain it all generators parking with burning of hydrocarbons, means that for the passage of a single engine on hydrogen we use other 10 motors on the hydrocarbons only for the liquefaction and storage of hydrogen required on a single engine, actually global pollution has increased by about 10 times and perhaps even more. Can be used in some places renewable energy sources, clean (Wind the sun, etc) for storing hydrogen necessary, in which case we can speak of a real elimination of global pollution by passing on fuel hydrogen, but still so we can speak of a real economy of energy since the energy used for obtaining a full of hydrogen, there would have been fed directly at least ten motor vehicles equipped with electric motors.

On the other hand, as long as the more we get electricity and thermal energy and by the burning of hydrocarbons and the electric motors of the cars are supplied with electric batteries charged from a socket, the losses resulting and pollution of the environment are much higher than if we have used fossil fuels directly on cars equipped with heat engines classic or modern. Today there is only a single variant of the electric motor auto convenient, namely that at which the electrical accumulator is loaded directly from the solar radiation sensor from the photovoltaic cells distributed directly on the automobile (Petrescu and Petrescu, 2003). The problem in which we stood seems to have no solution for time, so the idea of the use of hydrogen stored it can be said that has failed, for the time being, hydrogen being implemented more to buses, i.e., where can be built more easily a special base for bottling of hydrogen and of the supply to the buses.
Even so it would be better that hydrogen to be entered first on all the buses in circulation which comply with the condition that the energy used for the storage of hydrogen to be obtained directly from renewable sources, because the current consuming from the public network for each engine past we use hydrogen ten other engines on hydrocarbons to generate the current that it stores the hydrogen (it is well known that on the planet of electrical energy is still obtain and from the hydrocarbons, in percentage raised by about 40\%), (Heywood, 1988).

Otherwise, if we loosen water directly in the hydrogen and oxygen and we will immediately send the hydrogen for their combustion directly into an engine, or in a specialized burner (burning full making it in cells) the implementation of hydrogen as a fuel would be one of great success. Here experiments have come very far, because of the slight separation of water in her components using the ultraviolet some or in the mini cellular honeycomb type using nanotechnologies (Naima and Liazid, 2013).

Magnetic motors (combined and with the electromagnetic) are only at the beginning, but they offer us a happy perspective especially in the aviation industry. At first, they will not be able to be used in direct actuation of the transmission but will generate an electrical current that will fill the accumulator from which it will actually power the engine (probably an electric motor).

A great relaxation was the introduction of hybrid cars, in particular with the burning of hydrogen in the cells (fuel cells), but even although already used on a large scale in Asia, Europe and the Americas over 10 years, method is today only a drop in the "Ocean" cars on hydrocarbons (Karikalan et al., 2013; Aversa et al., 2016a-c; Ronney et al., 1994).

Hybrid cars have helped them very much to the production of a real change, but their percentage planetary drive is still very small compared with conventional cars which already reached to a park in circulation which has exceeded from more time, one billion (Sethusundaram et al., 2013; Zahari et al., 2013). For the time being, in addition to the hydrocarbon reserves existing, it is announced the discovery of new supply, in particular gases which although are more difficult to extract, have the advantage of existing in very large quantities. In this way, we will be able to extend the life of the "old Otto" and that of "Santa Claus Diesel" (Leet et al., 2004; Mirsayar et al., 2017).

The shale gas has represented a real bubble of oxygen for the Blue Planet and for the heat engines. With them was able to diminish again the fossil fuel price, after decades of the energetic crisis and the price increases on the barrel of oil (De Falco et al., 2013). 
Even so, it will still need engineers and researchers, in order to improve the thermal engines used (the power group), the transmissions of power together with the train of the driving and even the motor vehicle in its assembly. Reduce fuel consumption for a given type of vehicle, for one hundred miles traveled, has occurred in constantly from 1980 and up to the present and will continue to do so in the future (Sapate and Tikekar, 2013).

Even if it will grow hybrids and cars with electric motors, let us not forget that they must be loaded with electric current which in general is obtained through the combustion of fossil, mainly in the oil and natural gas in proportion the current planetary of about $40 \%$. People burn petroleum (oil) in large thermal centrals, to keep warm, have hot water and electricity for domestic consumption, street, industrial, commercial, etc. and part of this energy we will spend it additional on (auto)vehicles with electric motors, but global energy issue does not be solved and the crisis even deepens. It so happened when we forced electrified rail for trains, when $\mathrm{i}$ generalized reminding the subway, consuming suddenly more electric current product especially from oil; oil consumption has sharply increased and the price or had to take a giant leap.

The appearance of the worst of this (which seems to have gone unnoticed by the great governments of the contemporary world) is that pollution and consumption due to the additional combustion of petroleum, petroleum products and natural gas in the energy centrals of the world, they have grown very much and very suddenly, due to the increased consumption of electricity obtained in large part from the combustion of classic who are on the verge of extinction (the oil reserve of the earth could actually exhausted in the next 50-60 years if go on like this, as for the time being the new energies implemented, renewable energy sources and sustainable only if carried out for around $25 \%$ of the overall production efficiency, approximately $40 \%$ being still performed by the new biofuels, from biomass, of nuclear energy obtained by both fission and hydroelectric plants). For the time being wind energy, the solar, the obtained from the tide, from the waves of the seas and oceans of the thermal springs, chemical, or by various other routes, just touches now for around $20 \%$ of the worldwide production of energy (including the electric one). Probably generalize suddenly and electrical cars (although we are not ready yet for this), we will make a new blow the reserves of oil and natural gas so that instead of being to their life make such reserves at 100-200 years we will brief them at 30-40 years.
Fortunately (lately) has been developed very many biofuels, biomass and nuclear energy (so far that based on the reaction of nuclear fission).

They together and with hydropower, have managed to produce about $40 \%$ of energy actually consumed globally.

Alternative sources will take them by themselves a major unsuspected manipulation, but we wait for the energy provided by them to be much more consistency in the global percentage, in order to be able to us to rely on them in real mode (otherwise, we risk that all these alternative energies to remain just a sort of "fairy tale" in which it has invested so much with fewer results). Alternative sources were almost non-existent until the year 2010 when they started to develop very much (Ganapathi and Robinson, 2013).

Until when will be ready the new nuclear plants on fusion, mankind is obliged to ensure the energy resources necessary for the future it, in particular by sustainable energy renewable, cheap, clean, friendly.

As long as the renewable and sustainable will not be at least $80-90 \%$ of worldwide output energy, there is no point to replace today more other thermal engines of vehicles with electric motors.

Maybe only can we say that because of the Classic car (with heat engines) in the middle of the energy crisis and not only energy efficiency, of 1970 and until today), the production of cars and motor vehicles has increased at a brisk pace (but natural), instead of going down and they have been placed on the market and used. It was starting at the crisis of the world energy (in the 1970s) from around 200 million vehicles on the globe, it has reached the figure of approximately 350 million in 1980 (when he declared for the first time the energetic crisis and fuels, the world crisis), in 1990 there were some 500 million vehicles on the globe and in 1997 the number of vehicles registered at world level exceeded the figure of 600 million. In 2010 flows on the entire planet over 800 million vehicles. Already the number of road vehicles in circulation, which has increased by four times during the period of the crisis in 1970 and until 2010, reaching from 200 mil. to 800 mil., reached and one billion. Who could quickly remove from circulation a car park of a billion of motor vehicles and to replace it in its entirety with one electrified? With what money, when the increased efforts of the governments of all countries, can hardly to withdraw from circulation annually about 1 percent of the fleet of vehicles which exceed 20-30 years when they are in the movement?

Today the ideas and models for the car of the future have multiplied more than ever and grow further on a passing day. We are powerless witnesses to a barrage of new solutions on the engine or transmission of the motor 
vehicle. Hybrids which promised an immediate problem resolution (which they haven't brought so far) shall vary on a monthly basis.

Perhaps that is not bad to have touched a diversification an extreme. This betrays the technological revolution which we live in directly, but and the fact that we have some problems related to energy, fuels, pollution, etc, still outstanding, who ask for us and our models (patents) up to find some final forms and solutions (Feldman, 2008).

We can hear it more and more frequently of biofuels (Diesel thought first or engine for operation with biodiesel blends, more exactly with the vegetable oil extracted biological of the hazelnuts, but diesel fuel that when indigenous has managed to take the place of the biofuels at that time and then a very low price).

Recently it was born the idea of using seaweed to achieve superior fuel plant. Given the huge amount of algae that we could harvest in the world's oceans, the variant is really interesting (Petrescu et al., $2017 \mathrm{a}-\mathrm{v}$ ).

The MagLev (Magnetic Levitation) has been working successfully in China and Japan for many years once again demonstrating the superiority of the forces exerted by electromagnetic fields.

\section{The Hydrogen used as a Fuel at Automobile}

Otto cycle engines or those with internal combustion, in general, will have to adapt to the new fuel, hydrogen. It is composed of the core element (hydrogen) may be industrial extract from virtually any other element (or combination) by nuclear, chemical, photonic, through radiation, by burning, etc. (most easily hydrogen can be removed from the water by the decomposition of them in the constituent elements, hydrogen and oxygen; by the burning of hydrogen shall be rerun the water circuit undermining of her natural without loss and without pollution; another solution is to extract from water, the hydroxyl liquid). The hydrogen must be stored in the tanks with cells (honeycomb type) so there is no danger of explosion.

Hydrogen extracted from water by burning regenerates water and thus restoring its natural balance and additionally, direct hydrogen combustion of fourstroke engines do not produce noxious as it is today when we use petroleum fuels.

The hydrogen is extracted from water relatively easy (we already have several methods available) but found that it would be easier to separate water into oxygen $\mathrm{O}$ and hydroxyl HO. Hydroxyl group obtained is a brown liquid that burns very well and dissociation produced in this way consumes even less energy. Hydrogen must be stored in cylinders honeycomb because you have eliminated the danger of explosion; generally, it is stored under pressure, compressed into the liquid state.

Tested for a long time (along with other unconventional fuels such as methanol, ethanol, vegetable oils, etc.) at the beginning, hydrogen did not immediately give the expected results.

Hydrogen was tested mixtures and generally did not give good results in this way.

When they went to burn liquid hydrogen without mixed with other fuels, again there were problems.

Hydrogen was tried directly in existing internal combustion engines without modifications thereof, so it was natural that his burning not gives immediate results.

Hydrogen burns ten times faster than classic fuels, combustion processes so runs ten times faster. Logic would be to try to adopt an engine faster (Grunwald, 1980; Petrescu and Petrescu, 2003).

Hydrogen is the lightest element, a hydrogen atom normal nucleus having a single nucleon; a single nucleon in the nucleus, i.e., only one proton and no neutrons.

The element hydrogen, stored in a liquid state even at $-2520 \mathrm{C}$ is 10 (ten) times lighter than gasoline.

One $\mathrm{kg}$ of hydrogen develops nearly three times more heat than a $\mathrm{kg}$ of gasoline. However, a correct mixture air-hydrogen generates only $25 \%$ more heat compared to air-fuel mixture.

It is worth noting that while air-fuel mixture ignites within relatively low, air mixture burns hydrogen in a larger space.

Only 2-3 cubic $\mathrm{km}$ of water from oceanic if would be decomposed into hydrogen and oxygen, it could donate hydrogen fuel for the annual needs of global road transport. What would this possibly annual world consumption of $2-3 \mathrm{~km}^{3}$ of the total 1.37 billion $\mathrm{km} 3$ belonging ocean? Three $\mathrm{km}^{3}$ compared to the total planetary represents $2 * 10-7 \%$ from the oceanic water. This totally insignificant percentage of water consumed annually would not feel like missing. This totally insignificant percentage of water consumed annually would restore even in that year because by burning hydrogen is produced water instead. And what about the air quality would not be filled with carbon monoxide, carbon dioxide, that we might be able to restore the planet clean air, shields recovered and climate its initial soft and normal, that we could breathe normally again, our children and grandchildren. The tank of hydrogen represented in the last 40 years a problem as difficult as to braked during all these years submitting a dispute the problem of fuel of the future (hydrogen), more even than the "certain circles of oil chiefs, who saw in him a fearsome enemy, to be asleep on the possible long". 
Storing it safely effectively was a major problem. Fortunately today this problem is solved, fair and consistent manner.

There is a storage cylinder specially designed (see Fig. 1; HB-SC-0660-N) that can hold liquid hydrogen pressurized recommended for small vehicles (mopeds, motorcycles), or normal vehicles for the future when they use motors compact hydrogen; the cylinder is $38 \mathrm{~cm}$ long, weighing $6 \mathrm{~kg}$ and 660 stores it at a pressure of 4.5 $\mathrm{MPa}$ (pressure is determined at a temperature of 250 Celsius), (Amoresano et al., 2013).

Recommended ambient temperature between 5 and 600 Celsius will likely be lowered below somewhere in the future.

Currently, a large machine (heavy), such a cylinder provides a range of about $100 \mathrm{~km}$. He can easily upload only one stop specialist. Basically, this cylinder is multiplied in large tanks. For road vehicles, large and medium recommended a device composed of five such cylinders (see Fig. 2; HB-SS 3300).

Of storage capacity fivefold increase ranging from 660 [1] to 3300 [1] pressurized liquid hydrogen. A jeep will go with such a tank (filled initially) about $500 \mathrm{~km}$.

An important first step in this process is complex passing cars on liquid hydrogen (at least initially), stored in specially designed tanks (tanks of hydrogen) and preparing distribution stations of this type of fuel.

This step actually started by signing an agreement (agreement, protocol) between eight (8) major auto manufacturers, "Hydrogen agreement"; signing of the agreement in Germany we could call "a G8 of hydrogen", the "Group of 8 for hydrogen" or abbreviated "HG8".

Honda Motor Company has achieved first a motor vehicle which uses an electric motor compact and the electrical energy consumed on battery power is restored by a system which uses an electrical generator with the burning of the hydrogen cells; so we have a machine which burns hydrogen but is driven by an electric motor.

\section{New and Modern Electric Car}

In the following, we briefly introduce a new model of electric car, but a truly revolutionary model.

A group of students at the University of Technology in Eindhoven has created Stella luxury. A machine 4.5 meters in length, as dubious speaks on both the efficiency. All the ceiling is covered with 381 of the photovoltaic cells that would collect energy from the sun. A small battery (of only $15 \mathrm{kWh}$ ) charges stationary or at low speed (in maximum $45 \mathrm{~min}$ ) for a range (autonomy) of 1,000 km. A special software combines the energy stored in the battery with that captured on the way (Meet Stella Lux). At night, with the battery fully charged, Stella Lux keeps $640 \mathrm{~km}$ range under ideal conditions (Fig. 3). Because it's made of carbon fiber and aluminum, the car has only $380 \mathrm{~km}$, which helps to catch $125 \mathrm{~km} / \mathrm{h}$ top speed.

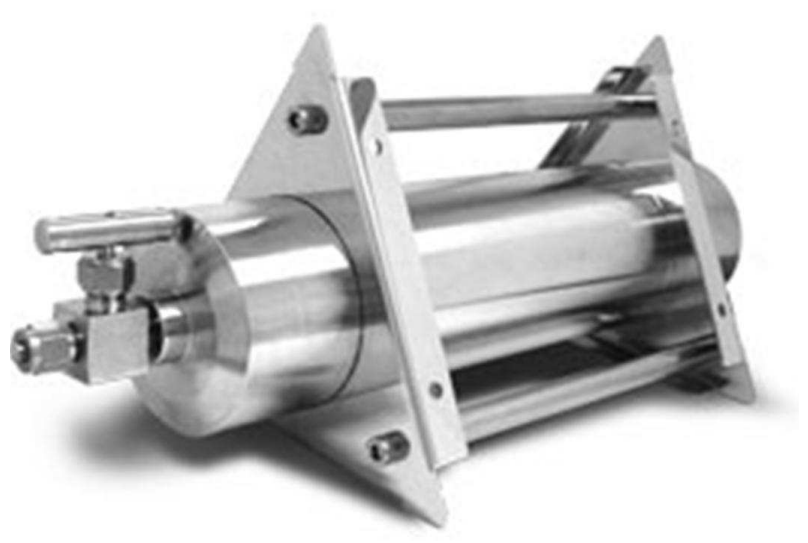

Fig. 1: A tank of hydrogen type HB-SC-0660-N

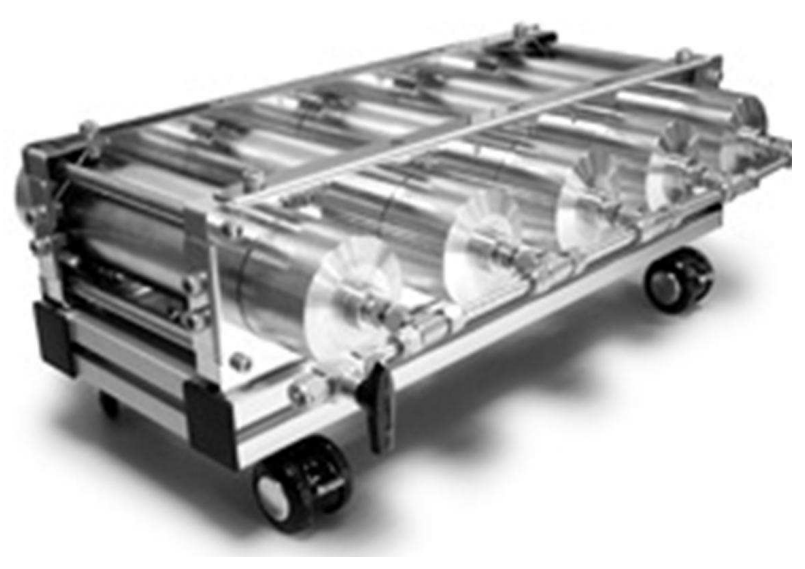

Fig. 2: A device composed of five such cylinders (HB-SS 3300)

The car has already participated in a marathon for solar vehicles. It made 3,000 $\mathrm{km}$ with three shortstops charging from the sun. The energy captured in the 3 short charge cycles did not cost anything. But if the captured energy in three charge cycles were taken at night or in bad weather, from a power outlet, the current consumed would have cost 5-6 dollars or the equivalent of about 5 liters petrol. Stella Lux is an intelligent machine that knows how to communicate with other cars and traffic through connection to the mobile phone of the owner. For example, if "hears" a car sirens intervention, automatically lowers the music from the car. And if you have your cell phone on you, you automatically open doors and it invites you inside. For 4 persons, Luxury Stella is very comfortable, everything is thought inside for ergonomics and relaxation, including the parcel shelf from which it operates all machine functions and ambient lights. The most important function is the one that interprets the digital amount of solar energy that can capture the same day. Thus, it can calculate the autonomy that said and you can indicate the best route via GPS, according to the electric charge current autonomy. 


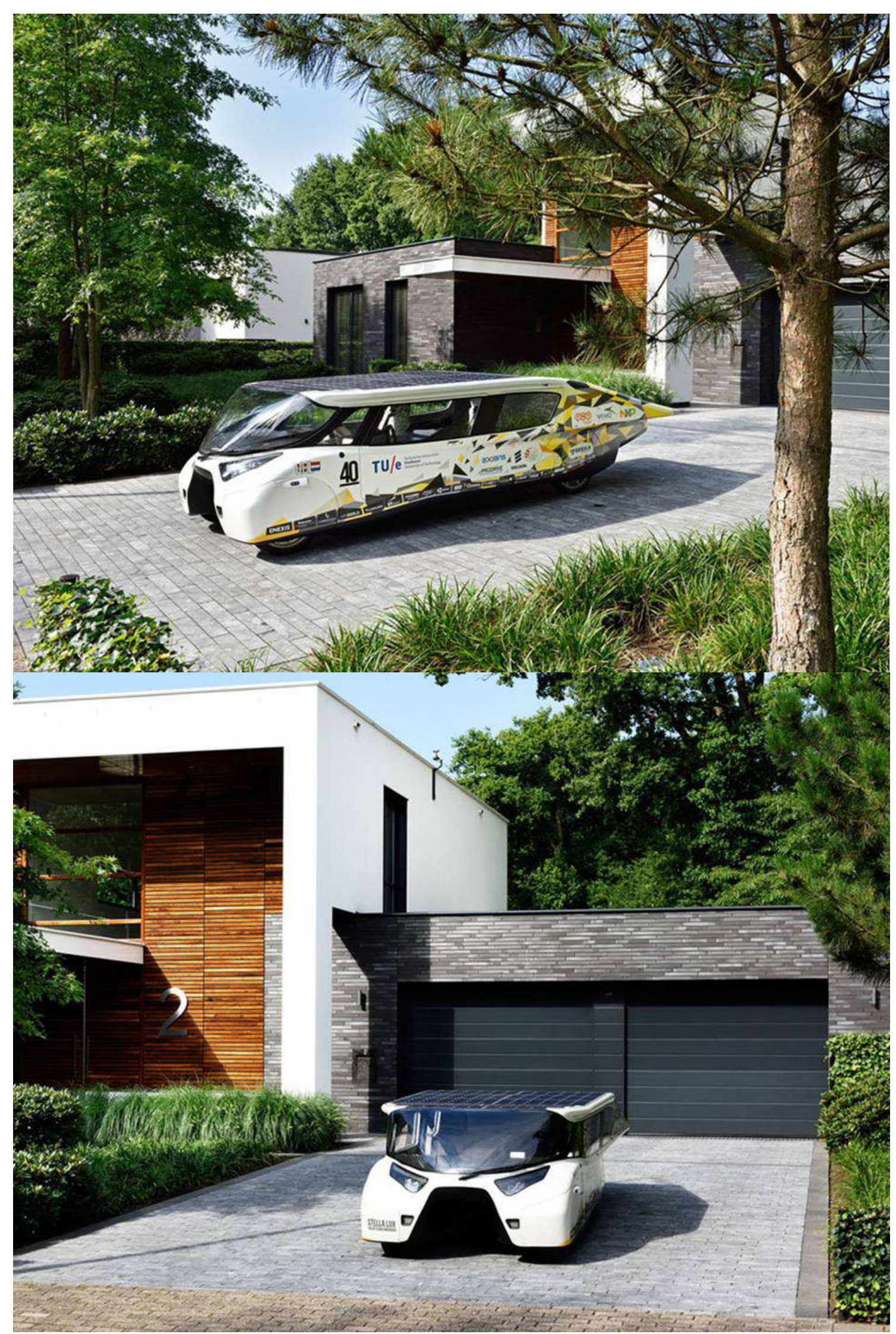




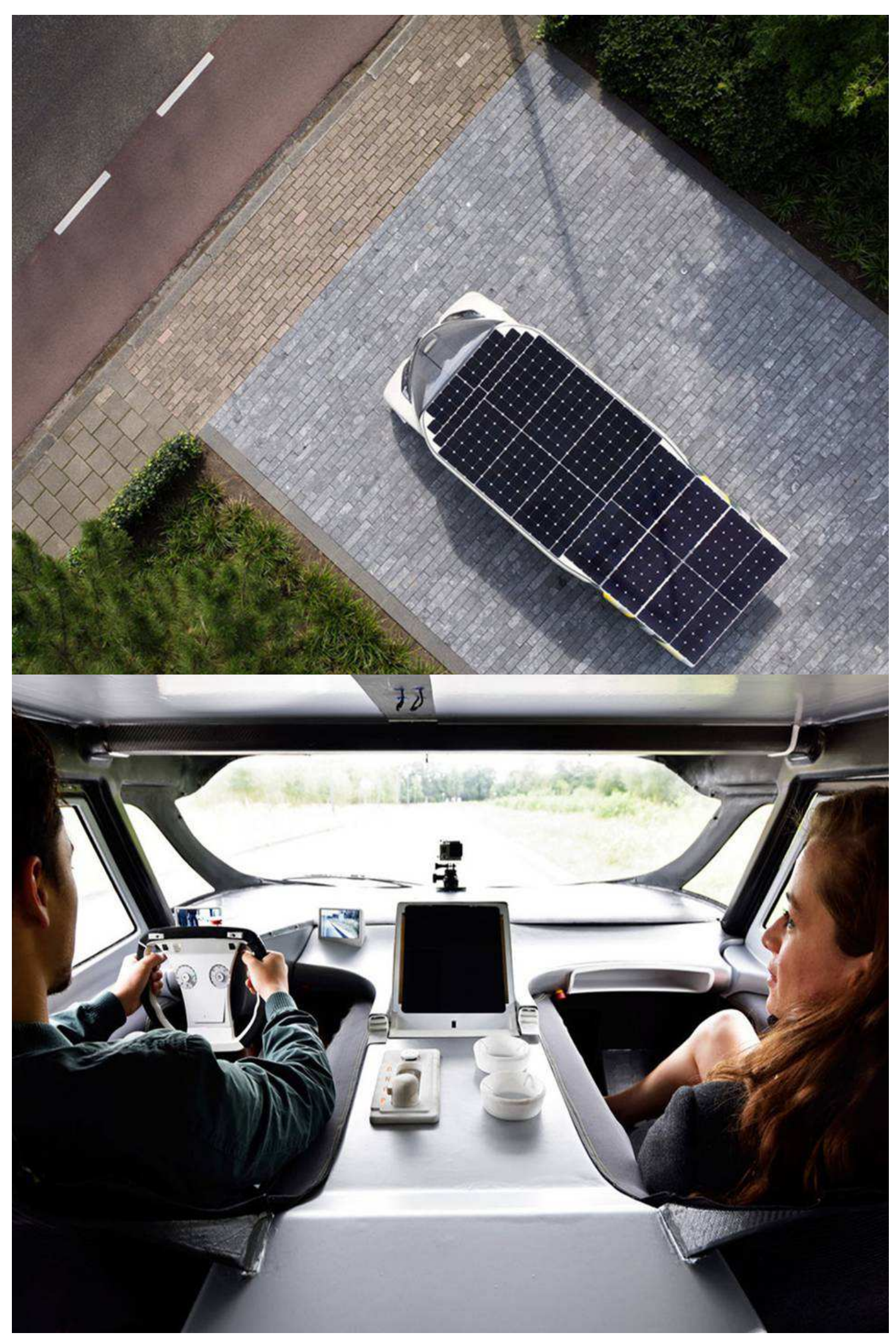




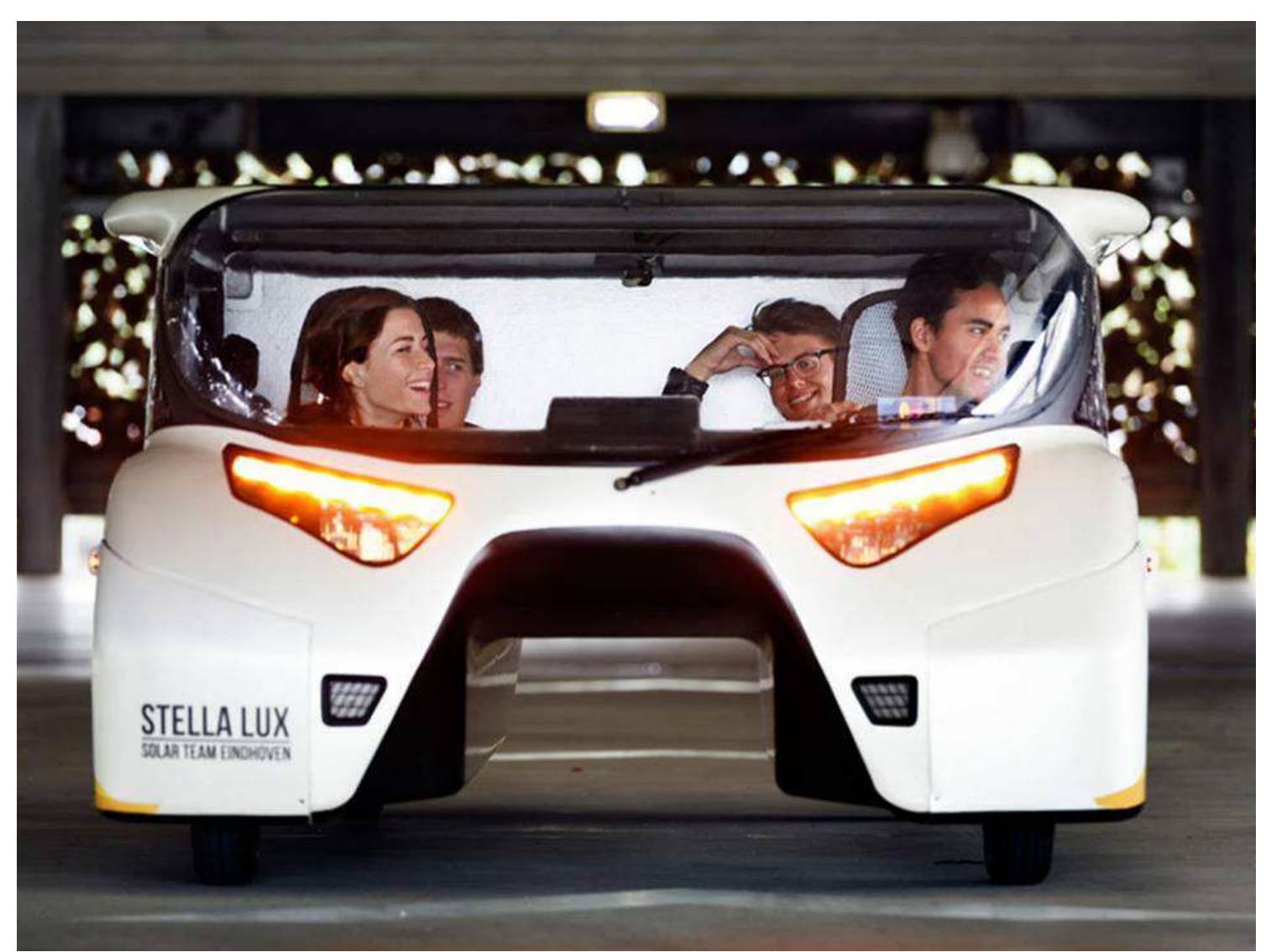

Fig. 3: Stella Lux, a very intelligent electric car

\section{Discussion}

The shipments were absolutely necessary at all times, but still, have polluted and damaged the environment.

Humanity is struggling between technological tests of deployment of new types of mild transport for the environment and the need to maintain still in the operation the machines already polluting products in large quantity, cheaper, more convenient economically, that customers have already been accustomed.

This work is trying to radiography the new technologies friendly environment who have been implemented or can be implemented in the future.

Are shown on the short and tests for the implementation of transport on the basis of the hydrogen. It also highlighted the possibilities of the changeover to the electric modern cars.

And what about the air quality would not be filled with carbon monoxide, carbon dioxide, that we might be able to restore the planet clean air, shields recovered and climate its initial soft and normal, that we could breathe normally again, our children and grandchildren.

Otto cycle engines or those with internal combustion, in general, will have to adapt to the new fuel, hydrogen.

It is composed of the core element (hydrogen) may be industrial extract from virtually any other element (or combination) by nuclear, chemical, photonic, through radiation, by burning, etc. (most easily hydrogen can be removed from the water by the decomposition of them in the constituent elements, hydrogen and oxygen; by the burning of hydrogen shall be rerun the water circuit undermining of her natural without loss and without pollution; another solution is to extract from water, the hydroxyl liquid).

The hydrogen must be stored in the tanks with cells (honeycomb type) so there is no danger of explosion.

Hydrogen extracted from water by burning regenerates water and thus restoring its natural balance and additionally, direct hydrogen combustion of fourstroke engines do not produce noxious as it is today when we use petroleum fuels.

The hydrogen is extracted from water relatively easy (we already have several methods available) but found that it would be easier to separate water into oxygen $\mathrm{O}$ and hydroxyl HO.

Hydroxyl group obtained is a brown liquid that burns very well and dissociation produced in this way consumes even less energy.

Hydrogen must be stored in cylinders honeycomb because you have eliminated the danger of explosion; generally, it is stored under pressure, compressed into a liquid state. 
Tested for a long time (along with other unconventional fuels such as methanol, ethanol, vegetable oils, etc.) at the beginning, hydrogen did not immediately give the expected results.

Hydrogen was tested mixtures and generally did not give good results in this way.

When they went to burn liquid hydrogen without mixed with other fuels, again there were problems.

Hydrogen was tried directly in existing internal combustion engines without modifications thereof, so it was natural that his burning not gives immediate results.

Hydrogen burns ten times faster than classic fuels, combustion processes so runs ten times faster. Logic would be to try to adopt an engine faster.

Hydrogen is the lightest element, a hydrogen atom normal nucleus having a single nucleon; a single nucleon in the nucleus, i.e., only one proton and no neutrons.

The element hydrogen, stored in a liquid state even at $-2520 \mathrm{C}$ is 10 (ten) times lighter than gasoline.

One $\mathrm{kg}$ of hydrogen develops nearly three times more heat than a $\mathrm{kg}$ of gasoline.

However, a correct mixture air-hydrogen generates only $25 \%$ more heat compared to air-fuel mixture.

It is worth noting that while air-fuel mixture ignites within relatively low, air mixture burns hydrogen in a larger space.

Only 2-3 cubic $\mathrm{km}$ of water from oceanic if would be decomposed into hydrogen and oxygen, it could donate hydrogen fuel for the annual needs of global road transport.

What would this possibly annual world consumption of 2-3 km3 of the total 1.37 billion $\mathrm{km} 3$ belonging ocean? Three $\mathrm{km}^{3}$ compared to the total planetary represents $2 * 10-7 \%$ from the oceanic water. This totally insignificant percentage of water consumed annually would not feel like missing.

This totally insignificant percentage of water consumed annually would restore even in that year because by burning hydrogen is produced water instead.

And what about the air quality would not be filled with carbon monoxide, carbon dioxide, that we might be able to restore the planet clean air, shields recovered and climate its initial soft and normal, that we could breathe normally again, our children and grandchildren.

In the final part of this work was briefly introduced a new model of electric car, but a truly revolutionary model.

A group of students at the University of Technology in Eindhoven has created Stella luxury. A machine 4.5 meters in length, as dubious speaks on both the efficiency. All the ceiling is covered with 381 of the photovoltaic cells that would collect energy from the sun. A small battery (of only $15 \mathrm{kWh}$ ) charges stationary or at low speed (in maximum $45 \mathrm{~min}$ ) for a range (autonomy) of 1,000 km.

A special software combines the energy stored in the battery with that captured on the way. At night, with the battery fully charged, Stella Lux keeps $640 \mathrm{~km}$ range under ideal conditions. Because it's made of carbon fiber and aluminum, the car has only $380 \mathrm{~km}$, which helps to catch $125 \mathrm{~km} / \mathrm{h}$ top speed.

The car has already participated in a marathon for solar vehicles. It made $3,000 \mathrm{~km}$ with three shortstops charging from the sun. The energy captured in the 3 short charge cycles did not cost anything.

But if the captured energy in three charge cycles were taken at night or in bad weather, from a power outlet, the current consumed would have cost 5-6 dollars or the equivalent of about 5 liters petrol.

Do not look at its aspect. Such a gem car, made only with current possibilities of a group of enthusiastic students, wants to show us, first of all, that it is possible.

If we want a better life and a cleaner planet, if we want to be healthier, now is the time for a major shift in transportation.

There are endless reserves of hydrogen, for example from water. If we really want to finish this problem with maximum success, then we can also implement water cars that actually work with hydrogen released from water by decomposing the water into its component parts even on the vehicle, the tank being filled with water and on the way to the engine or to a burner, the water is decomposed into hydrogen and oxygen by means of a special device, oxygen being released into the atmosphere that enriches itself after millions of years of lack of oxygen in the air and hydrogen will be directed to the vehicle's engine or more correctly to a specialized fuel cell fuel burner, so that the thermal energy obtained from its combustion is chemically transformed into electric current can be stored in a specialized battery of the vehicle, which will eventually work with specialized electric motors.

A beautiful option is to get electricity directly from the sun with photocells. A train could only be driven by the energy obtained by the locomotive worn all over the photocells, or maybe some wagons would also need to be similarly equipped. Imagine your electrified wireless trains and especially without the high voltage used today. It is a beautiful dream that can be achieved today.

On all vehicles that go on or through the water and who consume huge amounts of gasoline or diesel and pollute the planet's waters, not to mention the high cost of fossil fuels you are in the process of disappearing, it's already possible to convert vehicle models that work with water, or more precisely with hydrogen extracted from the water, from the water they are moving, instead of operating with expensive and polluting hydrocarbons that are in an extinction fase.

Some might say that for now such new technologies are difficult to implement for heavy vehicles such as trucks and buses on the other hand electric buses have big problems when starting in winter, in cold areas, or in other special areas where full electric engines do not 
perform well. Agree but for such situations, gas engines can be implemented immediately, if it is goodwill. We know that cars gas are no longer a novelty and no difficulty in implementing their already existing in almost all world points of supply, unlike points supply hydrogen which were implemented slowly and only in a few cities . In addition, the gas represents the classic fuel on hydrocarbons which almost do not pollute (the pollution resulting from their burning is very low). Today, if we can talk about a prolongation of gasoline and diesel for another 40-50 years, this is due to the introduction of electric transports and nuclear power plants as well as solar and wind power, but quite different things are for gas. Gases were present on the planet in much greater quantities than oil and moreover, other deposits have been discovered, not to mention the real revolution produced by the use of deep-sea gas, the so-called shale gas, which previously could not be exploited due to old technologies. Today can talk about real gas reserves for several hundred years or even for a thousand years. This is especially due to extraction and shale gases, which are very deep in rock shale. The gas burns completely and almost does not pollute of course, it is a shame to burn them for electric or thermal power when we have nuclear, solar, wind and hydro power stations, but on the other hand, we can't leave them and use them just for the home cooker when they are found in sufficient quantities and do not pollute the atmosphere as petroleum products or coal and wood do.

The fuel cell programs that have started hard and have evolved even more difficult, should not be stopped in any way, in order not to lose what has already been achieved. It would then be rational that all buses (or most of their buses) where they can not electrify be passed on to the gas. Then the trucks will follow the same bus route. The big car makers, which have come to record production on diesel and gasoline engines, will have to start cutting down these productions and start producing electric cars, gas, or fuel cell in a more significant proportion. The trains need to be fully electrified and trains with photocells can also be introduced. All vehicles that go on water or under water must already begin converting to the fuel cell and will soon be refurbished to work with hydrogen or even hydrogen extracted directly from the water. The future sounds pink! But we still have to insist on him!

\section{Conclusion}

The shipments were absolutely necessary at all times, but still have polluted and damaged the environment.

Humanity is struggling between technological tests of deployment of new types of mild transport for the environment and the need to maintain still in the operation the machines already polluting products in large quantity, cheaper, more convenient economically, that customers have already been accustomed.
Only 2-3 cubic $\mathrm{km}$ of water from oceanic if would be decomposed into hydrogen and oxygen, it could donate hydrogen fuel for the annual needs of global road transport.

A group of students at the University of Technology in Eindhoven has created Stella luxury. A machine 4.5 meters in length, as dubious speaks on both the efficiency. All the ceiling is covered with 381 of the photovoltaic cells that would collect energy from the sun. A small battery (of only $15 \mathrm{kWh}$ ) charges stationary or at low speed (in maximum $45 \mathrm{~min}$ ) for a range (autonomy) of 1,000 km.

Special software combines the energy stored in the battery with that captured on the way. At night, with the battery fully charged, Stella Lux keeps $640 \mathrm{~km}$ range under ideal conditions. Because it's made of carbon fiber and aluminum, the car has only $380 \mathrm{~km}$, which helps to catch $125 \mathrm{~km} / \mathrm{h}$ top speed.

The car has already participated in a marathon for solar vehicles. It made $3,000 \mathrm{~km}$ with three short stops charging from the sun. The energy captured in the 3 short charge cycles did not cost anything.

But if the captured energy in three charge cycles were taken at night or in bad weather, from a power outlet, the current consumed would have cost 5-6 dollars or the equivalent of about 5 liters petrol.

The fuel cell programs that have started hard and have evolved even more difficult, should not be stopped in any way, in order not to lose what has already been achieved. It would then be rational that all buses (or most of their buses) where they cannot electrify be passed on to the gas. Then the trucks will follow the same bus route. The big car makers, which have come to record production on diesel and gasoline engines, will have to start cutting down these productions and start producing electric cars, gas, or fuel cell in a more significant proportion. The trains need to be fully electrified and trains with photocells can also be introduced. All vehicles that go on water or under water must already begin converting to the fuel cell and will soon be refurbished to work with hydrogen or even hydrogen extracted directly from the water. The future sounds pink! But we still have to insist on him!

\section{Acknowledgment}

The work was appreciated by teams of professors from the departments of automobiles from several universities in Romania and Italy. This text was acknowledged and appreciated by Professor Guanying Chen Harbin Institute of Technology and SUNY Buffalo China, Associate Professor Aniello Riccio SECONDA UNIVERSITA' DEGLI STUDI DI NAPOLI Italy, Dr. (Ms.) Shweta Agarwala Senior Research Scientist at Singapore Center for 3D Printing Nanyang Technological University Singapore, whom we thanks and in this way. 


\section{Author's Contributions}

All the authors contributed equally to prepare, develop and carry out this manuscript.

\section{Ethics}

This article is original. Authors declare that are not ethical issues that may arise after the publication of this manuscript.

\section{References}

Amoresano, A., V. Avagliano, V. Niola and G. Quaremba, 2013. The assessment of the in-cylinder pressure by means of the morpho-dynamical vibration analysis-methodology and application. IREME J., 7: 999-1006.

Anderson, R.B., 1984. The Fischer-Tropsch Synthesis. 1st Edn., Academic Press, Orlando, ISBN-10: 0120584603, pp: 301.

Aversa, R., Petrescu, R., Apicella, A., \& Petrescu, F.I.T. 2017. Modern Transportation and Photovoltaic Energy for Urban Ecotourism. Transylvanian Review Of Administrative Sciences, 13(SI), 5-20. doi:http://dx.doi.org/10.24193/tras.SI2017.1

Aversa, R., R.V.V. Petrescu, F.I.T. Petrescu and A. Apicella, 2016a. Biomimetic and evolutionary design driven innovation in sustainable products development. Am. J. Eng. Applied Sci., 9: 1027-1036. DOI: 10.3844/ajeassp.2016.1027.1036

Aversa, R., F. Tamburrino, R.V.V. Petrescu, F.I.T. Petrescu and M. Artur et al., $2016 \mathrm{~b}$. Biomechanically inspired shape memory effect machines driven by muscle like Acting NiTi alloys. Am. J. Applied Sci., 13: 1264.1271. DOI: 10.3844/ajassp.2016.1264.1271

Aversa, R., V. Perrotta, R.V.V. Petrescu, C. Misiano and F.I.T. Petrescu et al., 2016c. From structural colors to super-hydrophobicity and achromatic transparent protective coatings: Ion plating plasma assisted $\mathrm{TiO} 2$ and $\mathrm{SiO} 2$ nano-film deposition. Am. J. Eng. Applied Sci., 9: 1037-1045.

DOI: 10.3844/ajeassp.2016.1037.1045

Barrett, G.W. and E.P. Odum, 2000. The twenty-first century: The world at carrying capacity. BioScience, 50: 363-368.

DOI:

$10.1641 / 0006-$ 3568(2000)050[0363:TTFCTW]2.3.CO;2

De Falco, D., G. Di Massa, S. Pagano and S. Strano, 2013. Motorcycle handlebar dynamic response: Theoretical and experimental investigation. IREME J., 7: 795-801.

EU Bulletin, 2005. Thematic strategy on air pollution. EU Bull.

EU Bulletin, 2004. Existing community measures relating to sources of environmental noise. EU Bull.
EU Bulletin, 2001. The Clean Air for Europe (CAFE) programme: Towards a thematic strategy for air quality. EU Bull.

EU Bulletin, 1996. The green paper on future noise policy. EU Bull.

Feldman, B., 2008. The hybrid automobile and the Atkinson Cycle. Phys. Teacher., 46: 420-422.

Ganapathi, P. and Y. Robinson, 2013. Experimental investigation on the performance, emission and combustion characteristics of a diesel engine fuelled with polymer oil - ethanol blends. IREME J., 7: 919-924.

Grunwald, B., 1980. Teoria, calculul şi construcţia motoarelor pentru autovehicule rutiere. Editura didacticã şi pedagogic. Bucureşti.

Heywood, J.B., 1988. Internal Combustion Engine Fundamentals. 1st Edn., McGraw-Hill.

Karikalan, L., M. Chandrasekaran and K. Sudhagar, 2013. Comparative studies on vegetable oil usage in CI engines as an alternative to diesel fuel. IREME J., 7: 705-715.

Leet, J.A., S. Simescu, K. Froelund, L.G. Dodge and C.E. Roberts, 2010. Emissions solutions for 2007 and 2010 heavy-duty diesel engines. Proceedings of the SAE World Congress and Exhibition, (WCE' 10), Detroit, Michigan. DOI: 10.4271/2004-01-0124

Mahalingam, S. and B.R. Ramesh Bapu, 2013. Experimental and emission analysis of rubber seed oil and jatropha oil blends with diesel in compression ignition engine. IREME J., 7: 955-959.

Meet Stella Lux: The energy positive family car.: https://www.youtube.com/watch? $\mathrm{v}=$ nuND8epNLec

Mirsayar, M.M., V.A. Joneidi, R.V.V. Petrescu, F.I.T. Petrescu and F. Berto, 2017. Extended MTSN criterion for fracture analysis of soda lime glass. Eng. Fracture Mechan., 178: 50-59. DOI: 10.1016/j.engfracmech.2017.04.018

Naima, K. and A. Liazid, 2013. Numerical investigation on combustion behaviors of direct-injection spark ignition engine fueled with CNG-hydrogen blends. IREME J., 7: 652-663.

Petrescu, R.V.V., R. Aversa, A. Apicella, F. Berto and S. Li et al., 2016a. Ecosphere protection through green energy. Am. J. Applied Sci., 13: 1027-1032. DOI: 10.3844/ajassp.2016.1027.1032

Petrescu, F.I.T., A. Apicella, R.V.V. Petrescu, S.P. Kozaitis and R.B. Bucinell et al., 2016 b. Environmental protection through nuclear energy. Am. J. Applied Sci., 13: 941-946.

Petrescu, F.I.T. and J.K. Calautit, 2016c. About nano fusion and dynamic fusion. Am. J. Applied Sci., 13: 261-266.

Petrescu, F.I. and R.V. Petrescu, 2003. Câteva elemente privind îmbunătăţirea designului mecanismului motor. Proceedings of 8th National Symposium on GTD, (NSG' 03), Brasov, pp: 353-358. 
Petrescu, F.I., 2012. Teoria Mecanismelor: Curs Si Aplicatii. 1st Edn., CreateSpace Independent Publishing Platform, USA, ISBN-10: 1479293628, pp: 284.

Petrescu, R.V., R. Aversa, B. Akash, R. Bucinell and J. Corchado et al., 2017a. Testing by non-destructive control. Am. J. Eng. Applied Sci., 10: 568-583. DOI: $10.3844 /$ ajeassp.2017.568.583

Petrescu, R.V., R. Aversa, A. Apicella and F.I.T. Petrescu, 2017b. Transportation engineering. Am. J. Eng. Applied Sci., 10: 685-702. DOI: 10.3844/ajeassp.2017.685.702

Petrescu, R.V., R. Aversa, S. Kozaitis, A. Apicella and F.I.T. Petrescu, 2017c. The quality of transport and environmental protection, part I. Am. J. Eng. Applied Sci., 10: 738-755. DOI: 10.3844/ajeassp.2017.738.755

Petrescu, R.V., R. Aversa, B. Akash, R. Bucinell and J. Corchado et al., 2017d. Modern propulsions for aerospace-a review. J. Aircraft Spacecraft Technol., 1: 1-8. DOI: $10.3844 /$ jastsp.2017.1.8

Petrescu, R.V., R. Aversa, B. Akash, R. Bucinell and J. Corchado et al., 2017e. Modern propulsions for aerospace-part II. J. Aircraft Spacecraft Technol., 1: 9-17. DOI: 10.3844/jastsp.2017.9.17

Petrescu, R.V., R. Aversa, B. Akash, R. Bucinell and J. Corchado et al., 2017f. History of aviation-a short review. J. Aircraft Spacecraft Technol., 1: 30-49. DOI: 10.3844 /jastsp.2017.30.49

Petrescu, R.V., R. Aversa, B. Akash, R. Bucinell and J. Corchado et al., 2017g. Lockheed martin-a short review. J. Aircraft Spacecraft Technol., 1: 50-68. DOI: 10.3844 jastsp.2017.50.68

Petrescu, R.V., R. Aversa, B. Akash, J. Corchado and F. Berto et al., 2017h. Our universe. J. Aircraft Spacecraft Technol., 1: 69-79. DOI: 10.3844 jastsp.2017.69.79

Petrescu, R.V., R. Aversa, B. Akash, J. Corchado and F. Berto et al., 2017i. What is a UFO? J. Aircraft Spacecraft Technol., 1: 80-90.

DOI: 10.3844 jastsp.2017.80.90

Petrescu, R.V., R. Aversa, B. Akash, J. Corchado and F. Berto et al., 2017j. About bell helicopter FCX-001 concept aircraft-a short review. J. Aircraft Spacecraft Technol., 1: 91-96. DOI: 10.3844 /jastsp.2017.91.96

Petrescu, R.V., R. Aversa, B. Akash, J. Corchado and F. Berto et al., 2017k. Home at airbus. J. Aircraft Spacecraft Technol., 1: 97-118. DOI: 10.3844 /jastsp.2017.97.118

Petrescu, R.V., R. Aversa, B. Akash, J. Corchado and F. Berto et al., 20171. Airlander. J. Aircraft Spacecraft Technol., 1: 119-148.

DOI: $10.3844 /$ jastsp.2017.119.148
Petrescu, R.V., R. Aversa, B. Akash, J. Corchado and F. Berto et al., $2017 \mathrm{~m}$. When boeing is dreaming-a review. J. Aircraft Spacecraft Technol., 1: 149-161. DOI: 10.3844/jastsp.2017.149.161

Petrescu, R.V., R. Aversa, B. Akash, J. Corchado and F. Berto et al., 2017n. About Northrop Grumman. J. Aircraft Spacecraft Technol., 1: 162-185. DOI: 10.3844/jastsp.2017.162.185

Petrescu, R.V., R. Aversa, B. Akash, J. Corchado and F. Berto et al., 2017o. Some special aircraft. J. Aircraft Spacecraft Technol., 1: 186-203. DOI: 10.3844/jastsp.2017.186.203

Petrescu, R.V., R. Aversa, B. Akash, J. Corchado and F. Berto et al., 2017p. About helicopters. J. Aircraft Spacecraft Technol., 1: 204-223. DOI: 10.3844 /jastsp.2017.204.223

Petrescu, R.V., R. Aversa, B. Akash, F. Berto and A. Apicella et al., 2017q. The modern flight. J. Aircraft Spacecraft Technol., 1: 224-233. DOI: 10.3844 /jastsp.2017.224.233

Petrescu, R.V., R. Aversa, B. Akash, F. Berto and A. Apicella et al., 2017r. Sustainable energy for aerospace vessels. J. Aircraft Spacecraft Technol., 1: 234-240. DOI: 10.3844/jastsp.2017.234.240

Petrescu, R.V., R. Aversa, B. Akash, F. Berto and A. Apicella et al., 2017s. Unmanned helicopters. J. Aircraft Spacecraft Technol., 1: 241-248. DOI: $10.3844 /$ jastsp.2017.241.248

Petrescu, R.V., R. Aversa, B. Akash, F. Berto and A. Apicella et al., 2017t. Project HARP. J. Aircraft Spacecraft Technol., 1: 249-257. DOI: 10.3844 /jastsp.2017.249.257

Petrescu, R.V., R. Aversa, B. Akash, F. Berto and A. Apicella et al., 2017u. Presentation of romanian engineers who contributed to the development of global aeronautics-part I. J. Aircraft Spacecraft Technol., 1: 258-271. DOI: $10.3844 /$ jastsp. 2017.258.271

Petrescu, R.V., R. Aversa, B. Akash, F. Berto and A. Apicella et al., 2017v. A first-class ticket to the planet mars, please. J. Aircraft Spacecraft Technol., 1: 272-281. DOI: 10.3844/jastsp.2017.272.281

Ronney, P.D., M. Shoda, S.T. Waida and E.J. Durbin, 2008. Throttleless premixed-charge engines: Concept and experiment. J. Automobile Eng., 208: 13-24.

Sapate, K.D. and A.N. Tikekar, 2013. Engine mapping for improvement in fuel efficiency of two stroke SI engine. IREME, 7: 392-394.

Sethusundaram, P.P., K.P. Arulshri and K. Mylsamy, 2013. Biodiesel blend, fuel properties and its emission characteristics sterculia oil in diesel engine. IREME, 7: 925-929.

Zahari, I., M.A. Abras, N.I. Mat Arishad, S.F. Zainal and M.F. Muhamad, 2013. Experimental study to identify common engine part load conditions between Malaysian city driving and NEDC test. IREME, 7: 1152-1158. 